\title{
Number of progenies and repetitions for reciprocal full-sib recurrent selection programs in maize
}

\author{
Número de progênies e repetições para programas de seleção recorrente \\ recíproca de irmãos germanos em milho
}

\author{
Paula Mikaely Henrique Vieira ${ }^{*}\left(\mathbb{D}\right.$, Olinda Estefania Ocampos Báez ${ }^{2}$ (D), Brena Kelly da Silva Almeida ${ }^{1}$ (D), \\ Matheus Henrique Silveira Mendes ${ }^{3}$ (D) , João Cândido de Souza' ${ }^{1}$ (D)
}

\author{
'Universidade Federal de Lavras/UFLA, Lavras, MG, Brasil \\ ${ }^{2}$ Asociación Paraguaya de Obtentores Vegetales, Hernandarias, Paraguay \\ ${ }^{3}$ Syngenta Brasil, Angatuba, SP, Brasil \\ ${ }^{*}$ Corresponding author: paulamhvieira@gmail.com \\ Received in November 10, 2020 and approved in February 28, 2021
}

\begin{abstract}
For a reciprocal recurrent selection (RRS) program to succeed, it is essential to maintain genetic variability throughout the selection cycles and to obtain accurate estimates of genetic parameters, which in turn are directly related to the number of progenies and repetitions evaluated. This study evaluates the potential of maize progenies of the sixth cycle of RRS and proposes, using simulation methods, the ideal combination of the number of progenies and repetitions to employ in reciprocal full-sib recurrent selection. A total of 163 full-sib progenies were evaluated in a randomized block design with six repetitions. Based on the yield data, analysis of variance was carried out, and different scenarios were simulated using the Monte Carlo chain method. These scenarios varied in the number of repetitions (two, four, and six) and progenies (30 to 163). The contrast between progenies and controls was significant, revealing the potential of the progenies of the sixth cycle of RRS. The high magnitude of the selective accuracy $(0.77)$ was reflected in high estimates of heritability, which allowed for efficient phenotypic selection, obtaining selection gains of $14.07 \%$. From the estimates of phenotypic and genotypic variance, heritability, accuracy, and standard error, it was found that a repetition number above two results in drastic changes in the estimates of these parameters; however, with the use of 130 progenies, these estimates tend to stabilize, implying that a high number of progenies does not interfere decisively in the quality of most parameters, except for the limits of maximum and minimum variation.
\end{abstract}

Index terms: Zea mays L.; accuracy; genetic gain; grain yield.

\section{RESUMO}

Para o sucesso em programas de seleção recorrente recíproca (SRR) é essencial manter a variabilidade genética ao longo dos ciclos de seleção e obter estimativas precisas dos parâmetros genéticos, que por sua vez estão diretamente relacionados ao número de progênies e repetições avaliadas. Este estudo avalia o potencial de progênies de milho do sexto ciclo de SRR e propõe, por meio de métodos de simulação, a combinação ideal entre o número de progênies e repetições para emprego na SRR de irmãos germanos. 163 progênies de irmãos germanos foram avaliadas em um delineamento de blocos casualizados, com seis repetições. Baseado nos dados de produtividade, a análise de variância foi realizada e diferentes cenários foram simulados usando o método de cadeia de Monte Carlo. Esses cenários variaram em número de repetições (duas, quatro e seis) e progênies (30 a 163). O contraste entre progênies e testemunhas foi significativo, revelando o potencial das progênies do sexto ciclo da SRR. A alta acurácia seletiva (0.77) refletida em altas estimativas de herdabilidade, permitiu uma seleção fenotípica eficiente, obtendo ganhos com a seleção de 14.07\%. A partir das estimativas de variância fenotípica, genotípica, herdabilidade, acurácia seletiva e erro padrão, constatou-se que um número de repetições acima de dois resulta em mudanças drásticas nas estimativas desses parâmetros, e a partir de 130 progênies estas estimativas tendem a se estabilizarem, de modo que um número elevado de progênies não interfere de forma decisiva na qualidade da maioria dos parâmetros, exceto para os limites de variação máxima e mínima.

Termos para indexação: Zea mays L.; acurácia; ganho genético; produtividade de grãos. 


\section{INTRODUCTION}

Heterosis, or hybrid vigor, is one of the main phenomena responsible for success in the productivity of many crops (Fujimoto et al., 2018; Andorf et al., 2019). In maize breeding, heterosis can be exploited using reciprocal recurrent selection (RRS), a method in which additive and nonadditive effects are maximized to improve the hybridization between two populations of different heterotic groups (Comstock; Robinson; Harvey, 1949; Hallauer; Carena; Miranda Filho, 2010; Yu et al., 2020). Through RRS, improved populations are used as a source of parental lines for the production of high-performance hybrids (Betran; Hallauer, 1996; Kolawole et al., 2018; Ferreira Júnior et al., 2020).

For RRS success to continue over generations, there must be genetic variability in the population. In this case, the use of an ideal number of progenies allows for efficient sampling and coverage of the genetic variability presented in the population, reflecting realistic estimates about its potential. A limited effective number can result in inaccurate representation and lead to the loss of favorable alleles or the fixation of undesirable alleles (Falconer; Mackay, 1996).

To verify the efficiency of an RRS program and ensure successful selection, accurate estimates of genetic parameters must be measured at each cycle. Additionally, it is important to use an appropriate number of repetitions to provide a good estimate of the experimental error and consequently increase the accuracy and power of the statistical tests (Silva Filho, 2013; Storck et al., 2016; Ribeiro et al., 2017). The adequate number of repetitions and progenies to estimate genetic parameters and dissimilarity or to compare genotypes has been studied by several authors for the most diverse crops and traits (Matei et al., 2017; Cargnelutti Filho et al., 2018; Cargnelutti Filho; Toebe, 2020; Woyann et al., 2020).

The use of an ideal number of repetitions and progenies optimizes the breeding pipeline and guarantees successful selection. However, the number of progenies and repetitions should not be so large that it makes the installation of the experiment unfeasible in terms of execution, time, and cost or so small as to undermine the representativeness of genetic variability and low experimental precision. Therefore, more studies aiming to identify the ideal number of cultivars and repetitions in maize are necessary (Cargnelutti Filho et al., 2018). The objectives of this study were to assess the potential of populations in the sixth cycle of RRS, and obtain information on the best combination between the number of progenies evaluated and the number of repetitions for use in RRS, aiming to optimize the prediction of genetic components, accuracy and, consequently, selection gain in an RRS of full-sibs.

\section{MATERIAL AND METHODS}

\section{Plant material and experimental design}

A total of 163 full-sib maize progenies were obtained from two populations on the sixth cycle of RRS in experiments carried out in Lavras city $\left(21^{\circ} 12^{\prime} \mathrm{S}, 45^{\circ} 59^{\prime}\right.$ $\mathrm{W}$, and altitude of $918.84 \mathrm{~m}$ ), Minas Gerais state, Brazil. The RRS program was started in 2003, and the two base populations (A and B) were initially derived from two commercial single cross hybrids. Each population was obtained by random intercrossing of $3000 \mathrm{~F}_{1}$ plants of each simple hybrid in two isolated fields, which generated two populations in Hardy-Weinberg equilibrium.

The method used for the conduction of the RRS program is similar to that proposed by Souza Júnior (1987). In the first cycle (C0), 2000 seeds of each population (A and B) were sown in two continuous blocks. In each population, the prolific plants had the lower ears self-fertilized and the upper ears crossed in pairs with plants from the reciprocal population, obtaining $\mathrm{S}_{1}$ progenies and interpopulation full-sib progenies, respectively. The seeds of $S_{1}$ progenies were considered the unit of recombination, and full-sib progenies were used for evaluation. The interpopulation progenies were evaluated, and the $10 \%$ most productive progenies were selected. The $S_{1}$ seeds from the selected interpopulation progenies were recombined within each population to obtain populations " $\mathrm{A}$ " and "B" of cycle 1 (C1). Except for $\mathrm{C} 2$, where progenies of intrapopulation half-siblings were obtained, in the third, fourth, fifth, and sixth selection cycles, the procedures were the same as those performed for $\mathrm{C} 0$. To obtain full-sib progenies across the cycles, the populations were sown in alternating rows, with a spacing of 0.60 meters between rows and 0.25 meters between plants. Additional information on the management of these populations can be obtained from Reis et al. (2014).

The 163 full-sib progenies from the sixth cycle and the checks, comprising two single hybrids and two commercial double hybrids, were evaluated in a randomized block design (RBD) with six repetitions. The plots consisted of a $3.0 \mathrm{~m}$ line with a spacing of $0.60 \mathrm{~m}$ between lines and $0.25 \mathrm{~m}$ between plants, totaling 12 plants per plot. The fertilization used at the time of planting was 
$450 \mathrm{~kg} \mathrm{ha}^{-1} 08 \mathrm{~N}-28 \mathrm{~K}_{2} \mathrm{O}-16 \mathrm{P}_{2} \mathrm{O}_{5}$ fertilizer, and coverage was performed 25 days after planting with $200 \mathrm{~kg} \mathrm{ha}^{-1}$ urea.

The grain yield was evaluated based on the husked ear weight per plot ( $\mathrm{kg} / \mathrm{plot})$. The weight of the ears was corrected for the ideal stand using analysis of covariance and for grain humidity at $13 \%$.

\section{Statistical analysis}

The data of six repetitions of 163 progenies were subjected to analysis of variance (ANOVA) at 95\% probability, considering the model $Y_{i j}=\mu+p_{i}+r_{j}+e_{i j}$, where $Y_{i j}$ is the value observed in the plot that received treatment $i$, within repetition $j ; \mu$ is the general constant associated with the model; $p i$ is the random effect of treatment $i$; $r j$ is the random effect of repetition $j$; and eij is the random effect of the experimental error.

The components of genetic and phenotypic variance were estimated as described by Bernardo (2020a). $\operatorname{Genetic}\left(\sigma_{g}^{2}\right)$ and phenotypic $\left(\sigma_{p}^{2}\right)$ variance were obtained from the mean squares of progenies $\left(Q_{p}\right)$ and error $\left(Q_{e}\right)$, according to the following expressions: $\sigma_{g}^{2}=\left(Q_{p}-Q_{s}\right) / r$ and $\sigma_{p}^{2}=Q_{p} / r$, respectively, where $r$ is the number of repetitions.

The broad-sense heritability $\left(h^{2}\right)$ averages among progenies were estimated using the following expression: $h^{2}=\sigma_{g}^{2} / \sigma_{p}^{2}$. Errors associated with these estimates were obtained by the formula provided by Knapp, Stroup and Ross (1985). The selection gain $\left(G S=d s \cdot h^{2}\right)$ was estimated considering a selection intensity of $10 \%$, where $d s$ is the selection differential based on differences between the mean of the progenies selected and the overall mean, and $h^{2}$ is the heritability.

The experimental precision was estimated by the coefficient of experimental variation $\left(C V \%=\frac{100 \sqrt{Q_{e}}}{m}\right)$, where $m$ is the overall mean, and by the selective accuracy $\left(r_{\hat{g} g}=\left[\frac{\sigma_{g}^{2}}{\sigma_{g}^{2}+\sigma_{p}^{2} / r}\right]^{1 / 2}\right)$, using phenotypic variance between means of progenies, where $r$ is the number of repetitions, as proposed by Pimentel-Gomes (2009) and Resende and Duarte (2007).

The data from 163 progenies evaluated with six repetitions were used for the simulation via the Monte Carlo method, and the models were fitted using the $\mathrm{R}$ package 'parallel' version 4.0.2 (R Development Core Team, 2019). The coincidence of the results and the consistency of the simulated data were verified from the comparison between real data and simulated data with the same number of progenies and repetitions. A total of 45 different scenarios were simulated, using three repetitions per scenario, by varying the number of progenies (30, $40,50,60,70,80,90,100,110,120,130,140,150,160$ and 163) and repetitions (two, four and six). For each scenario, 5,000 simulations were carried out, and the models were run for 225,000 simulations, with a burnin of 1,000. In each simulation, genetic and phenotypic variances, selective accuracy, heritability, and selection gain were estimated from the progeny mean. Based on the 5,000 simulations, the amplitudes of variation between the minimum and maximum values and the associated standard errors were obtained. All analyses for this study were performed using R software (R Development Core Team, 2019).

\section{RESULTS AND DISCUSSION}

The gains in recurrent selection programs are dependent on the maintenance of genetic variability throughout the selection cycles. There was a significant effect of progeny $(p<0.05)$ on yield $(\mathrm{kg} / \mathrm{plot})$, which indicates the presence of genetic variability between the progenies of the sixth cycle of RRS and reveals the existence of differences in the complementarity of the crossings between the two populations (Table 1). These factors make it possible to identify superior genotypes and select the best combinations, which allows predicting success with selection and progress along the RRS program.

The contrast between progenies versus checks was significant $(p<0.05)$, indicating the average superiority of the progenies $(2.45 \mathrm{~kg} / \mathrm{plot})$ over the checks $(2.19 \mathrm{~kg} /$ plot) regarding grain yield. This allows for inference about the potential of the progenies for the generation of commercial hybrids.

In this study, a CV of $22.17 \%$ was obtained, which is considered an average experimental precision according to Pimentel-Gomes (2009). The observed estimate is close to what was found by Palomino, Carvalho and Ferreira (2000) (17\%) and Cargnelutti Filho and Storck (2007) (21.8\%).

The selective accuracy obtained was greater than 0.7 (0.77), which was considered adequate for progeny evaluation tests, revealing the high precision in the present work (Resende; Duarte, 2007), mainly due to the large number of repetitions used.

The heritability estimated in the broad sense was $60.36 \%$, with lower limits different from zero (ranging from 48.19 to $69.13 \%$ ). In the initial cycles of RRS ( 0 and 3 ) of the same populations evaluated in this study, Reis et al. (2014) obtained heritability values of 29.8 and $51.5 \%$, respectively. This increase in heritability across the cycles 
VIEIRA, P. M. H. et al.

of selection is indicative of the accumulation of favorable alleles in the populations with a consequent increase in genetic variability, and it reaffirms the efficiency of recurring selection. A heritability of $60.36 \%$ is considered high, which agrees with results obtained by Santos et al. (2007) and Cunha et al. (2012). Although we compared our heritability values with those of other authors, it is important to note that this parameter is intrinsic to the population studied and depends on how the phenotypic traits were evaluated, the experimental conditions, and the estimator used (Falconer; Mackay, 1996; Bernardo 2020a; Bernardo, 2020b). Therefore, such a comparison can be biased.

Table 1: Analysis of variance and parameter estimates for the grain yield of ears (kg/plot), involving all full-sib progenies.

\begin{tabular}{|c|c|c|c|}
\hline Source variation & DF & \multicolumn{2}{|c|}{ Mean square } \\
\hline Repetitions & 5 & \multicolumn{2}{|c|}{$1.0827^{\mathrm{ns}}$} \\
\hline Treatments & 166 & \multicolumn{2}{|c|}{$0.7435^{*}$} \\
\hline Progenies & 162 & \multicolumn{2}{|c|}{$0.7377^{\star}$} \\
\hline Checks & 3 & \multicolumn{2}{|c|}{$0.7640^{\mathrm{ns}}$} \\
\hline Prog. vs Checks & 1 & \multicolumn{2}{|c|}{$1.6183^{*}$} \\
\hline Residuals & 830 & \multicolumn{2}{|c|}{0.2946} \\
\hline \multicolumn{4}{|c|}{ Parameter estimates } \\
\hline Heritability (\%) & 60.36 & LL: 48.19 & UL: 69.13 \\
\hline Accuracy & 0.77 & & \\
\hline CV (\%) & 22.17 & & \\
\hline GS $(\%)^{1}$ & 14.07 & GS (kg plot $\left.{ }^{-1}\right)$ & 0.34 \\
\hline
\end{tabular}

* differs significantly at the $5 \%$ probability level; ns: does not differ significantly; ${ }^{1}$ percentage of selection intensity at $10 \%$. Legend: CV: coefficient of variation; GS: selection gain; LL: lower limit; UL: upper limit.

Heritability in the broad sense is dependent on genotypic and phenotypic variance. In cases where heritability is high, as obtained in this study, there is an indication of the presence of genetic variability between progenies and that phenotypic selection based on the mean of progenies can be applied successfully in this population (Allard, 1999).

The expected selection gain, based on a selection intensity of $10 \%$, was $14.07 \%$, similar to the value reported by Alves et al. (2015) (16\%), indicating that reciprocal recurrent selection was effective. Thus, high values of heritability result in high gains due to selection reliability. Pinto, Lima Neto and Souza Junior (2000) obtained a selection gain of $7.2 \%$ with recurrent selection using half- sib families. The difference between the values of selection gains obtained in this study and those from the work of Pinto, Lima Neto and Souza Junior (2000) may be because half-sib families exploit half of the additive variance when compared with full-sib families and different populations have their own genetic variability and structure.

The need to use an ideal number of progenies in breeding programs, or the appropriate effective number, aims to avoid genetic drift and loss of variability in traits after recurrent selection cycles and the consequent reduction in selection gains. As such, the genetic variances and selection gains must be ascertained over the cycles, as reported by Santos et al. (2007). Alternatively, for the estimates of these parameters to be as accurate as possible, an adequate number of repetitions is needed to eliminate sampling problems and minimize environmental variations.

The use of an adequate number of repetitions and progenies is important; however, the arbitrary increase in either number can become technically unfeasible. In an RRS program with the use of full-sib progenies, a large increase in the number of repetitions and/or progenies can make the experiment impractical. This is because the use of full-sib progenies as a selection unit and $S_{1}$ progenies for recombination, in comparison with half-sib progenies, demands more work since it is necessary to carry out self-fertilizations and simultaneous crossings with prolific plants. Therefore, when deciding on the number of progenies and repetitions, it is important to take into consideration the crop, the trait evaluated, the breeding method used, the maintenance of genetic variability and good experimental precision.

Simulation analyses show that the estimates of phenotypic variance among progeny sizes between 30 and 163 ranged from 0.223 to $0.221,0.147$ to 0.148 , and 0.123 to 0.122 for two, four, and six repetitions, respectively (Figure 1A). The standard error of phenotypic variance for 30 progenies ranged from $1.74 \%$ (two repetitions) to $0.89 \%$ (four repetitions) and $0.70 \%$ (six repetitions), while for 163 progenies, these values were $0.27 \%, 0.05 \%$, and $0.003 \%$ for two, four, and six repetitions, respectively. With increasing number of repetitions, the average phenotypic variance decreased, and the associated standard error was relatively insignificant. This is explained by analyzing the expression of the phenotypic variance. Hence, the increase in the number of repetitions led to a reduction in the phenotypic variance. The average phenotypic variance in this study did not vary much depending on the number of progenies. This may be because 5,000 Monte Carlo simulations were performed, which allowed for coverage of the entire sample space. 

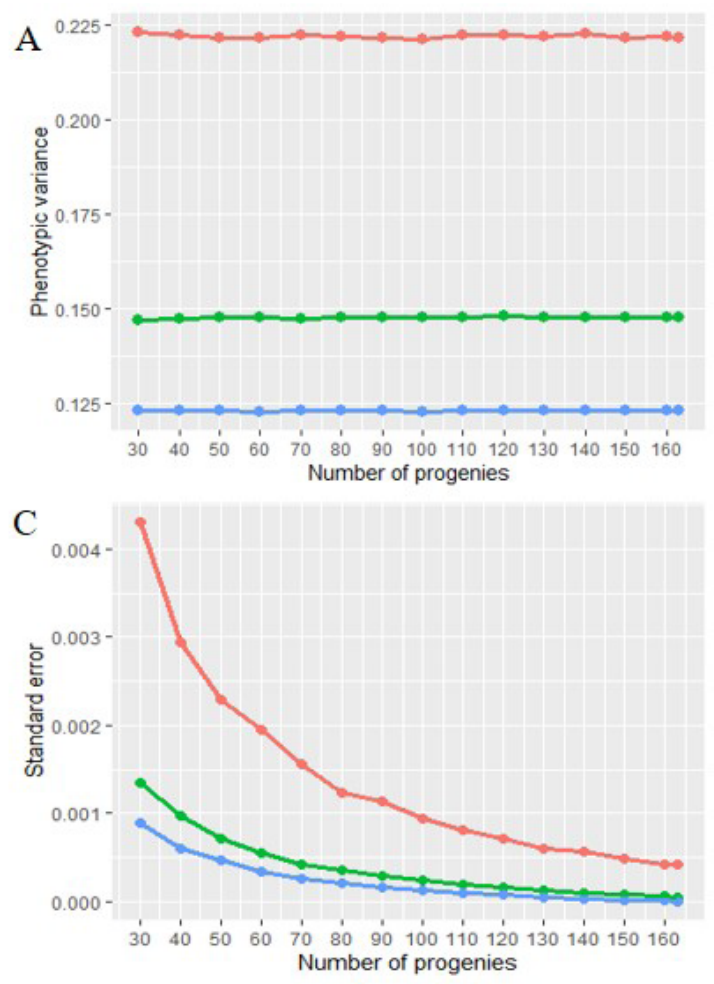

$\mathrm{E}$

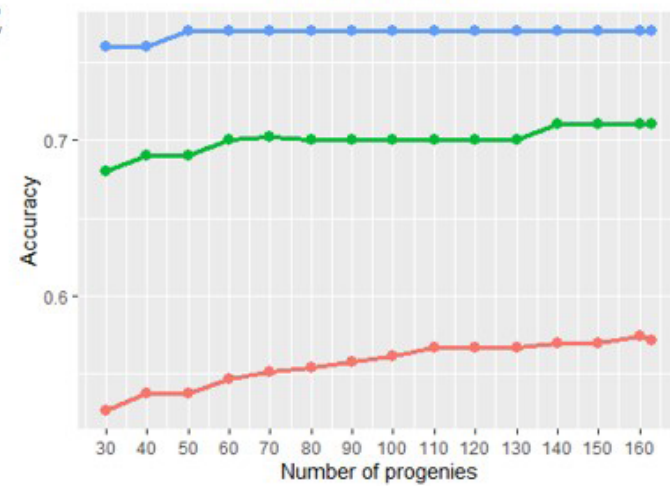

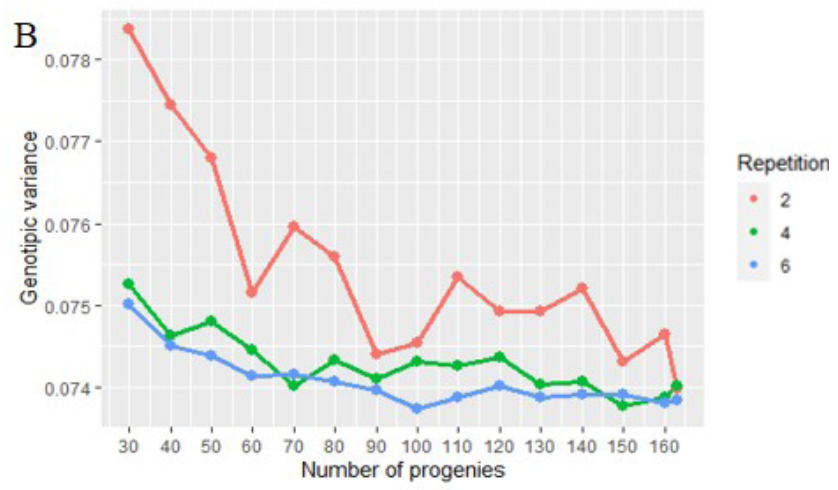
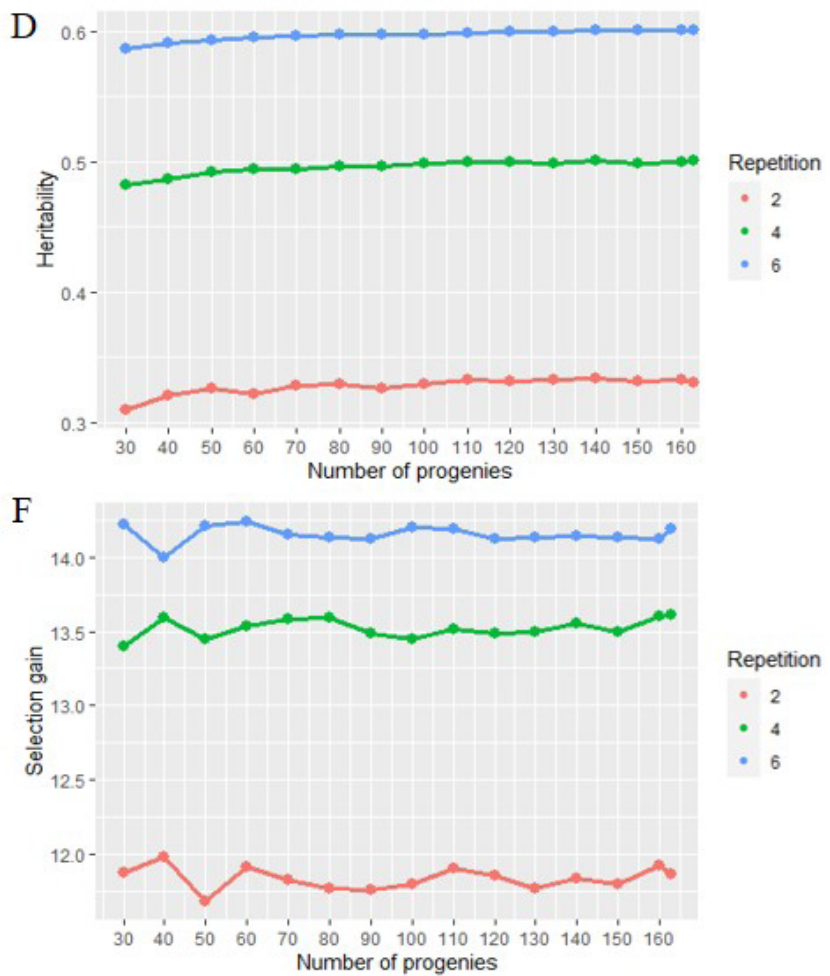

Figure 1: Estimates of the genetic and statistical parameters for the different numbers of progenies and repetitions. (A) Phenotypic variance; (B) genotypic variance; (C) standard error associated with the genotypic variance; (D) heritability; (E) accuracy; (F) standard error of the heritability of yield (kg/plot). All values were obtained using the simulation method for different numbers of progenies and repetitions.

Thus, the optimization of the number of repetitions is related to the reduction in phenotypic variance, regardless of the number of progenies used. The use of an adequate number of repetitions is of fundamental importance for reducing the experimental error and the phenotypic variance and, consequently, increasing the experimental precision (Ramalho; Ferreira; Oliveira, 2012; Gordón-Mendoza; CamargoBuitrago, 2015).
The estimates of genetic variance among 30 and 163 progenies ranged from 0.078 to $0.073,0.075$ to 0.074 , and 0.075 to 0.073 for two, four, and six repetitions, respectively. The average genetic variance did not vary much depending on the number of progenies and/or repetitions. However, when the results of two repetitions were analyzed, there was a tendency to overestimate the genetic variance when a smaller number of progenies was evaluated (Figure 1B). 
The estimates of standard error associated with genetic variances varied little with four and six repetitions, and from 100 or more progenies, these values hardly changed. The large variations presented when using small numbers of progenies show more pronounced genetic drift, which rejects the argument for the use of few progenies (Figure 1C).

The estimates of heritability among 30 and 163 progenies ranged from 0.30 to $0.33,0.48$ to 0.50 , and 0.58 to 0.60 for two, four, and six repetitions, respectively. The estimate of heritability showed a considerable increase with six repetitions compared to those evaluated with two repetitions. The estimates did not vary significantly when different numbers of progenies were used (Figure 1D).

The accuracy for 30 and 163 progenies ranged from 0.52 to $0.57,0.68$ to 0.71 , and 0.76 to 0.78 for two, four, and six repetitions, respectively. For selection gain, the estimates among 30 and 163 progenies ranged from 11.87 to $11.86,13.4$ to 13.61 , and 14.22 to 14.20 for two, four, and six repetitions, respectively (Figure $1 \mathrm{E}$ and $\mathrm{F}$ ). Similar to heritability, selective accuracy and selection gain showed a considerable increase when comparing datasets from two and six repetitions.

The selective accuracy is an important measure of the experimental quality. Selective accuracy allows the simultaneous consideration of the number of repetitions, genotypic variation between treatments and environmental variation in its estimation process, with added benefits of inference on the ordering of evaluated treatments, the precision of the predicted genotypic value, and a defined parametric space between 0 and 1 (Resende; Duarte, 2007). The highest estimates of accuracy were obtained with four and six repetitions and generate confidence in the data, which is crucial for selection, as it means that the data obtained correspond reliably to the genotype.

For genetic parameters, an increase in the number of repetitions leads to a decrease in phenotypic standard deviation and selection intensity. Since the change in the response to selection depends on the ratio between these two values, more intense selections are necessary to justify the additional use of repetitions when the heritability estimates are high, as reported by Silva Filho (2013).

In simulation studies developed by Matei et al. (2017), the ideal number of repetitions and adequate statistical analysis were evaluated to obtain reliable estimates of genetic parameters for the productivity trait in 324 soybean genotypes. When using two repetitions, it was possible to obtain a selective accuracy that was considered high $(<90)$. This suggests that the crop being evaluated may also influence the number of repetitions and progenies, as described by Silva Filho et al. (2013).
Torres et al. (2015) found that for the grain yield trait in cowpea, it is possible to identify superior genotypes with $79.19 \%$ accuracy when predicting their real value using four repetitions. A similar result was found in this study.

Cargnelutti Filho et al. (2018) studied the influence of the number of repetitions on experimental precision. In this experiment, 15 maize cultivars and 9 repetitions were used, and grain yield was evaluated. It was verified that the increase in the number of repetitions was essential to improve cultivar discrimination and was recommended as the benchmark for experiments with maize cultivars using six repetitions. These results match those of this study, suggesting that a greater number of repetitions results in more accurate estimates.

As also reported by Resende and Duarte (2007), the use of six repetitions is suitable for obtaining high selective accuracy, close to 0.90 . Despite this, many trials of maize (Cargnelutti Filho; Storck; Guadagnin, 2010), beans (Cargnelutti Filho; Storck, 2009), soybeans (Storck et al., 2009), and sugarcane (Cargnelutti Filho; Braga Junior; Lúcio, 2012) have shown high accuracy when using a relatively smaller number of repetitions.

Cargnelutti Filho, Storck and Guadagnin (2010) demonstrated that by considering an average value for the repetition coefficient, it is possible to identify superior cultivars for grain yield, with an accuracy of $81 \%$, with four repetitions. Catapatti et al. (2008) observed that the number of repetitions significantly influenced the differences between means of genotypes for several traits, including grain yield, with differences being larger when more than four repetitions were used. In this study, we suggested the use of a number of repetitions equal to or greater than four to guarantee experimental precision.

The associated amplitudes of genotypic and phenotypic variations were very high in small samples, whereas with the increase in the number of progenies evaluated, the amplitudes decreased considerably (Figure 2A and B). Thus, the parameters studied oscillated more with relatively small numbers of progenies, while with larger numbers, 100 or more progenies, the estimates showed a tendency to stabilize. Similarly, it is also appreciable that the estimates of genetic parameters varied little with four and six repetitions. Therefore, the gains in experimental precision when using a greater number of repetitions in evaluation tests must be contrasted with the increase in costs and labor (Cargnelutti Filho; Storck; Guadagnin, 2010; Cargnelutti Filho; Braga Júnior; Lúcio, 2012).

Pinto, Lima Neto and Souza Junior (2000), using half-sib and $\mathrm{S}_{1}$ progenies, observed that in all the traits analyzed, the parameters studied oscillated more in small samples, while in larger samples, approximately 175 to 200 

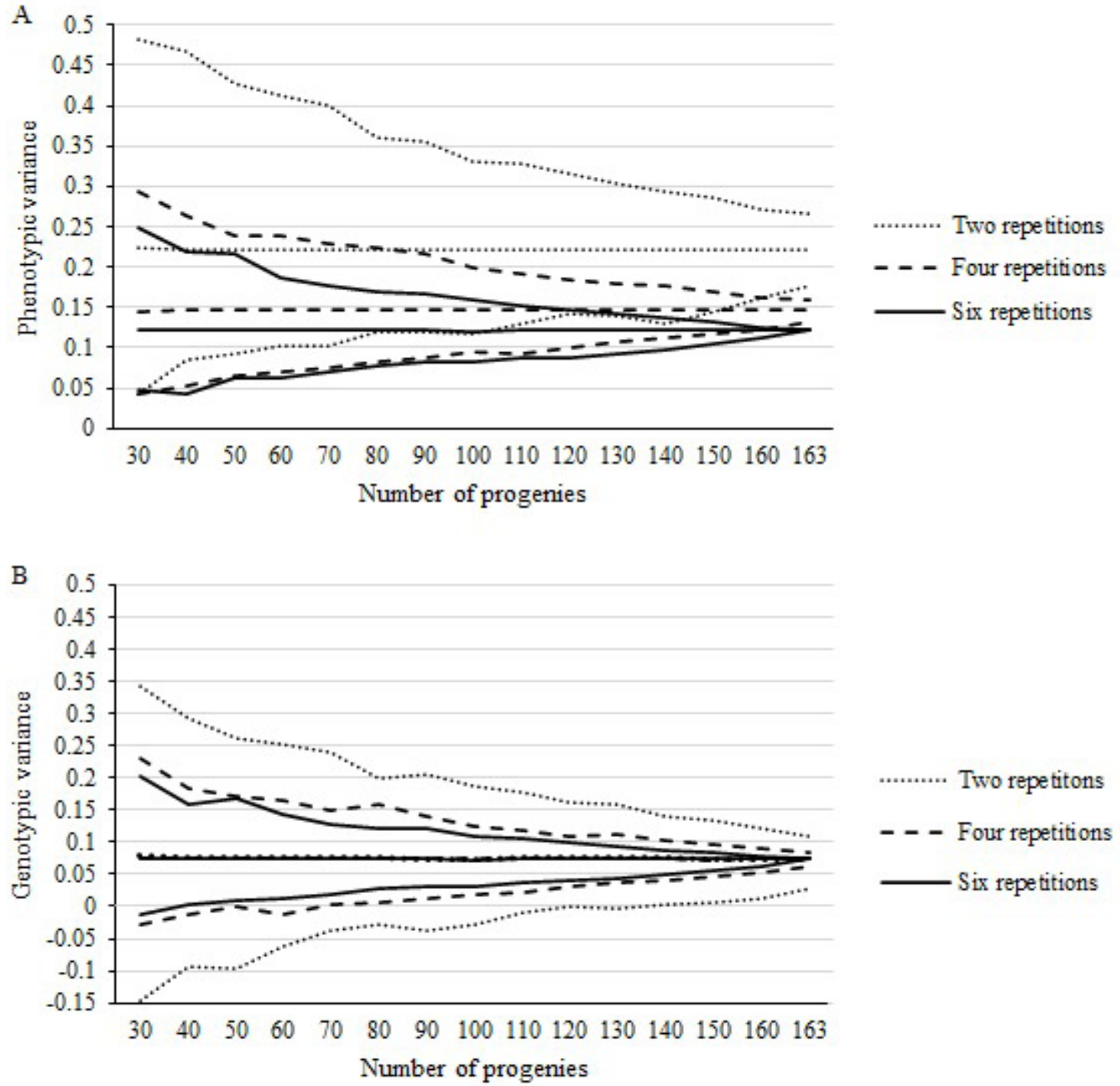

Figure 2: Amplitudes (minimum, median, and maximum) of the estimates of phenotypic (A) and genotypic (B) variances for the different numbers of progenies and repetitions.

progenies, the estimates stabilized. In this study, with 130 or more full-sib progenies and four to six repetitions, the values of genotypic variance and standard error were already stable, whereas with two repetitions, these values still showed great variation. Therefore, using at least 130 progenies and four or more repetitions would be the most suitable parameters for evaluating the grain yield trait in maize.

\section{CONCLUSIONS}

The populations from the sixth cycle of RRS are promising in the continuation of a reciprocal recurrent selection program due to obtaining experimental hybrids that are superior to checks. RRS is an efficient method to accumulate favorable alleles over multiple cycles in maize populations, and this method allows for the extraction of high-performance lines for hybrid maize production. The amplitudes of the estimates of the parameters studied oscillate less when at least 130 progenies are used with four repetitions, allowing for accurate estimates of genetic and phenotypic variance, as well as a reliable estimate of heritability and selection gain. 


\section{ACKNOWLEDGMENTS}

The authors wish to thank the following Brazilian agencies, $\mathrm{CNPq}$ (Conselho Nacional de Desenvolvimento Científico e Tecnológico), FAPEMIG (Fundação de Amparo à Pesquisa do Estado de Minas Gerais) and CAPES (Coordenação de Aperfeiçoamento de Pessoal de Nível Superior), for their financial support of this research and for providing the research grant to the authors.

\section{REFERENCES}

ALLARD, R. W. Principles of plant breeding. New York: John Willey and Sons, 1999. 254p.

ALVES, N. B. et al. Evaluation of progenies from the fifth reciprocal recurrent selection cycle in maize. Genetics and Molecular Research, 14(3):8236-8243, 2015.

ANDORF, C. et al. Technological advances in maize breeding: Past, present and future. Theoretical and Applied Genetics, 132:817-849, 2019.

BERNARDO, R. Breeding for quantitative traits in plants. Woodbury: Stemma Press, 2020a. 422p.

BERNARDO, R. Reinventing quantitative genetics for plant breeding: Something old, something new, something borrowed, something BLUE. Heredity, 125:375-385, 2020b.

BETRAN, F. J.; HALLAUER, A. R. Hybrid improvement after reciprocal recurrent selection in BSSS and BSCB1 maize populations. Maydica, 41:25-33, 1996.

CARGNELUTTI FILHO, A.; STORCK, L. Estatísticas de avaliação da precisão experimental em ensaios de cultivares de milho. Pesquisa Agropecuária Brasileira, 42(1):17-24, 2007.

CARGNELUTTI FILHO, A.; STORCK, L. Medidas do grau de precisão experimental em ensaios de competição de cultivares de milho. Pesquisa Agropecuária Brasileira, 44(2):111-117, 2009.

CARGNELUTTI FILHO, A.; STORCK, L.; GUADAGNIN, J. P. Número de repetições para a comparação de cultivares de milho. Ciência Rural, 40(5):1023-1030, 2010.

CARGNELUTTI FILHO, A.; BRAGA JUNIOR, R. L. C.; LÚCIO, A. D. Medidas de precisão experimental e número de repetições em ensaios de genótipos de cana-de-acucar. Pesquisa Agropecuária Brasileira, 47(10):1413-1421, 2012.

CARGNELUTTI FILHO, A. et al. Number of replicates and experimental precision statistics in corn. Pesquisa Agropecuária Brasileira, 53(11):1213-1221, 2018.
CARGNELUTTI FILHO, A.; TOEBE, M. Sufficient number of replicates for estimation of dissimilarity measures among maize cultivars. Revista Brasileira de Milho e Sorgo, 19:1-14, 2020.

CATAPATTI, T. R. et al. Tamanho de amostra e número de repetições para avaliação de caracteres agronômicos em milho-pipoca. Ciência e Agrotecnologia, 32(3):855-862, 2008.

COMSTOCK, R. E.; ROBINSON, H. F.; HARVEY, P. H. A breeding procedure designed to make maximum use of both general and specific combining ability. Agronomy Journal, 41(8):360-367, 1949.

CUNHA, K. S. et al. Full-sib reciprocal recurrent selection in the maize populations Cimmyt and Piranão. Genetics and Molecular Research, 11(3):3398-3408, 2012.

FALCONER, D. S.; MACKAYT. F. C. Introduction to quantitative genetics. London, Longman, 1996. 463p.

FERREIRA JÚNIOR, J. A. et al. Genetic progress in 20 years of reciprocal recurrent selection in maize. Functional Plant Breeding Journal, 2(1):13-23, 2020.

FUJIMOTO, R. et al. Recent research on the mechanism of heterosis is important for crop and vegetable breeding systems. Breeding Science, 68(2):145-158, 2018.

GORDÓN-MENDOZA, R.; CAMARGO-BUITRAGO, I. Selección de estadísticos para la estimación de la precisión experimental en ensayos de maíz. Agronomía Mesoamericana, 26(1):55-63, 2015.

HALLAUER, A. R.; CARENA, M.J.; MIRANDA FILHO, J. Quantitative genetics in maize breeding. New York: Springer, 2010. $680 p$.

KNAPP, S. J.; STROUP, W. W.; ROSS, W. M. Exact confidence intervals for heritability on a progeny mean basis. Crop Science, 25(1):192-194, 1985.

KOLAWOLE, A. O. et al. Genetic advance in grain yield and other traits in two tropical maize composites developed via reciprocal recurrent selection. Crop Science, 58(6):23602369, 2018.

MATEI, G. et al. Methods of analysis and number of replicates for trials with large numbers of soybean genotypes. Ciência Rural, 47(4):1-7, 2017.

PALOMINO, E. C.; RAMALHO, M. A. P.; FERREIRA, D. F. Tamanho de amostra para avaliação de famílias de meios-irmãos de milho. Pesquisa Agropecuária Brasileira, 35(7): 14331439, 2000. 
PIMENTEL-GOMES, F. E. Curso de estatística experimental. Piracicaba: Editora FEALQ, 2009. 451p.

PINTO, R. M.; LIMA NETO, F. P.; SOUZA JUNIOR, C. L. Estimativa do número apropriado de progênies $S_{1}$ para seleção recorrente em milho. Pesquisa Agropecuária Brasileira, 35(1):63-73, 2000.

R DEVELOPMENT CORE TEAM. R: A language and environment for statistical computing. R Foundation for Statistical Computing, Vienna, Austria: 2019. Available in: < https://www.r-project.org/>. Access in: February, 20, 2020.

RAMALHO, M. A. P.; FERREIRA, D. F.; OliVeirA, A. C. de. Experimentação em genética e melhoramento de plantas. Lavras: Editora UFLA, 2012. 305p.

REIS, M. C. dos et al. Estimates for genetic variance components in reciprocal recurrent selection in populations derived from maize single-cross hybrids. The Scientific World Journal, 2014:1-7, 2014.

RESENDE, M. D. V.; DUARTE, J. B. Precisão e controle de qualidade em experimentos de avaliação de cultivares. Pesquisa Agropecuária Tropical, 37(3):182-194, 2007.

RIBEIRO, N. D. et al. Experimental precision of grain yield components and selection of superior common bean lines. Euphytica, 290:1-11, 2017.
SANTOS, M. F. et al. Responses to selection and changes in combining ability after three cycles of a modified reciprocal recurrent selection in maize. Euphytica, 157(1-2):185-194, 2007.

SILVA FILHO, J. L. Optimizing the number of progenies and replications in plant breeding experiments. Crop Breeding and Applied Biotechnology, 13(3):151-157, 2013.

SOUZA JÚNIOR, C. L. Reciprocal recurrent selection with halfsib progenies obtained alternately fromnon-inbred (SO) and inbred (S1) plants in maize. Maydica, 22:19-31, 1987.

STORCK, L. et al. Método de Papadakis e número de repetições em experimentos de soja. Ciência Rural, 39(4):977-982, 2009.

STORCK, L. et al. Experimentação vegetal. Santa Maria: UFSM, 2016. 200p.

TORRES, F. E. et al. Número de repetições para avaliação de caracteres em genótipos de feijão-caupi. Bragantia, 74(2):161-168, 2015.

WOYANN, L. G. et al. Optimal number of replications and test locations for soybean yield trials in Brazil. Euphytica, 216(11):1-9, 2020.

YU, K. et al. Large-scale analysis of combining ability and heterosis for development of hybrid maize breeding strategies using diverse germplasm resources. Frontiers in Plant Science, 11:1-16, 2020. 